\title{
Nilai-Nilai yang Terkandung pada Tradisi Paru Udu dalam Ritual Joka Ju Masyarakat Mbuliwaralau Kabupaten Ende Nusa Tenggara Timur Indonesia
}

\author{
Wayan Resmini' ${ }^{1}$, Abdul Sakban ${ }^{2}$, Abdurahman Fauzam³ \\ 1Pendidikan Pancasila dan Kewarganegaraan, Universitas Muhammadiyah Mataram, Email: wayanresmini@gmail.com \\ 2Pendidikan Pancasila dan Kewarganegaraan, Universitas Muhammadiyah Mataram, Email: sakban.elfath@yahoo.co.id \\ 3Pendidikan Pancasila dan Kewarganegaraan, Universitas Muhammadiyah Mataram, Email: abdurahmanfauzam@gmail.com
}

INFO ARTIKEL
Riwayat Artikel:
Diterima: $\quad$ 12-Agustus-
2019
Disetujui: $25-S e p t e m b e r-$
2019

\section{Kata Kunci:}

Nilai

Tradisi

Paru Udu

Joka Ju

Mbuliwaralau

Ende

\begin{abstract}
ABSTRAK
Abstrak: Budaya merupakan cipta, rasa dan karsa manusia atau, dapat diartikan dengan halhal yang berkaitan dengan budi atau akal. Hasil akal atau pemikiran, cipta dan karya manusia merupakan suatu wujud kebudayaan yang selalu berkembang dalam masyarakat, yang dimana pemikiran, perbuatan atau tindakan-tindakan yang dilakukan oleh manusia secara terus-menerus pada akhirnyaakan melahirkan sebuah tradisi. Tradisi Paru Udu memiliki nilai yang berbeda dengan tradisi dengan daerah lainnya yang ada di Indonesia. Tujuan penelitian yaitu untuk mengetahui pelaksanaan tradisi Paru Udu dalam ritual Joka Ju di Desa Mbuliwaralau, dan nilai-nilai yang terkandung di dalam pelaksanaan tradisi Paru Udu dalam ritual Joka Ju. Subyek penelitian yaitu ketua adat, tokoh adat dan tokoh masyarakat. Metode penelitian yang digunakan adalah metode kualitatif dengan pendekatan deskriptif. Teknik pengumpulan data mengunakan observasi, wawancara dan dokumentasi. Sedangkan analisis data menggunakan metode analisis kualitatif bersifat deskriptif dengan melakukan reduksi data, penyajian data dan penarikan kesimpulan. Hasil penelitian menunjukan bahwa tradisi tersebut mengandung nilai sosial, nilai budaya, dan nilai ekonomi. Nilai social meliputi nilai material nilai vital dan nilai rohani. Nilai rohani meliputi nilai religius dan nilai moral yang didalamnya terdapat nilai kerukunan, nilai musyawarah, nilai kebersamaan dan nilai gotongroyong.
\end{abstract}

\begin{abstract}
Culture is human creativity, taste and intention or, can be interpreted with matters relating to reason or reason. The results of reason or thought, human creativity and work is a form of culture that is always developing in society, where thoughts, actions or actions carried out by humans continuously will eventually give birth to a tradition. The Paru Udu tradition has a different value from the tradition with other regions in Indonesia. The research objective is to determine the implementation of the Paru Udu tradition in the Joka Ju ritual in Mbuliwaralau Village, and the values contained in the implementation of the Paru Udu tradition in the Joka Ju ritual. The subjects of the study were the traditional leaders, traditional leaders and community leaders. The research method used is a qualitative method with a descriptive approach. Data collection techniques using observation, interviews and documentation. While the data analysis uses descriptive qualitative analysis methods by reducing data, presenting data and drawing conclusions. The results showed that the tradition contained social values, cultural values, and economic values. Social values include material values, vital values and spiritual values. Spiritual values include religious values and moral values in which there are values of harmony, values of deliberation, values of togetherness and values of mutual cooperation.
\end{abstract}

\section{A. LATAR BELAKANG}

Kebudayaan adalah totalitas latar belakang, sistem nilai, lembaga, dan perilaku hidup serta perwujudan yang khas pada suatu masyarakat. Itu merupakan gagasan, tindakan dan hasil karya manusia untuk memenuhi kehidupannya dengan cara belajar. Kebudayaan menjadi sekaligus identitas masyarakat yang bersangkutan, sehingga dalam kenyataannya, tidak semua masyarakat memiliki kebudayaan yang sama.
Hubungan manusia dengan kebudayaan sangatlah erat sehingga pada hakikatnya disebut makhluk budaya. Budaya merupakan cipta, rasa dan karsa manusia atau, dapat diartikan dengan hal-hal yang berkaitan dengan budi atau akal. Hasil akal atau pemikiran, cipta dan karya manusia merupakan suatu wujud kebudayaan yang selalu berkembang dalam masyarakat, yang dimana pemikiran, perbuatan atau tindakan-tindakan yang dilakukan oleh manusia secara terus-menerus pada akhirnyaakan melahirkan sebuah tradisi. Tradisi 
merupakan adat kebiasaan yang masih dijalankan dalam masyarakat atau kebiasaan yang dilakukan secara turuntemurun yang berasal dari masa lalu namun masih ada hingga kini dan belum dihancurkan atau dirusak, memiliki cerita tersendiri bagi masyarakatnya.

Setiap daerah memiliki tradisi dan keunikannya masing-masing. Tradisi-tradisi disetiap daerah juga memiliki tata cara pelaksanaan yang berbeda-beda. Tradisi yang dianggap oleh masyarakat pendukungnya masih bernilai positif akan terus dipertahankan, sementara tradisi yang dianggap tidak sesuai lagi dengan perkembangan zaman, seperti saat ini dikenal sebagai zaman moderen, persaingan kehidupan berjalan begitu ketat, maka tradisi yang tidak sesuai lagi akan ditinggalkan oleh masyarakat. Akan tetapi, tidak dapat dipungkiri bahwa ditengah kehidupan globalisasi seperti sekarang ini, masih banyak tradisi diberbagai daerah masih terus dipertahankan keberadaannya. Salah satunya adalah masyarakat suku Lio yang berada di Kabupaten Ende, Pulau Flores, Provinsi Nusa Tenggara Timur.

Masyarakat suku Lio dikenal sebagai masyarakat religius yang perilaku kesehariannya banyak dipengaruhi oleh alam pikiran yang bersifat spiritual. Masyarakat suku Lio dalam kehidupan sehari-hari memiliki hubungan istimewa dengan alam serta dikenal juga sebagai masyarakat yang menjunjung tinggi tradisi. Masyarkat suku Lio sendiri memiliki banyak tradisi yang bertujuan untuk menjaga kerukunan, keselamatan, dan bentuk syukur kepada Tuhan.

Tradisi yang dilakukan masyarakat suku Lio Kabupaten Ende diantaranya adalah tradisi Paki Tana Neka Watu adalah upacara musim tanam padi dan jagung, tradisi Keti Uta atau Ka Poka yaitu upacara yang dilaksanakan untuk menyongsong panen padi, dan tradisi atau ritual Joka $\mathrm{Ju}$ adalah upacara untuk menolak bala dan hama tanaman serta tradisi Paru Udu yaitu tradis yang dilakukan untuk menghidar dari bala atau marabahaya yang akan menyerang masyarakat. Dimana tradisi-tradisi ini masih dilakukan dan dipertahankan oleh masyarakat suku Lio hingga saat ini. Dari tradisi-tradisi tersebut di atas, ada salah satu tradisi yang paling unik. Yang dimana, tradisi ini hanya dilakukan oleh masyarakat suku Lio pada Desa Mbuliwaralau dan tidak terdapat di daerah manapun khususnya suku Lio Kabupaten Ende, yaitu tradisi Paru $\mathrm{Udu}[1]$.

Desa Mbuliwaralau merupakan desa yang terletak diantara Desa Keli Samba dan Kecamatan Wolojita yang terletak di lereng bukit. Kondisi ini membuat Desa Mbuliwaralau masih asri dan kehidupan masyarakatnya kental akan budaya dan tradisi. Hampir sebagian penduduknya bermata pencaharian sebagai petani. Desa ini masih menghormati dan mempertahankan tradisi Paru Udu sebagai salah satu bentuk nilai dan warisan budaya nenek moyangnya.
Tradisi Paru Udu adalah tradisi yang dilaksanakan sekali dalam setahun dalam konteks penanaman padi, jagung dan palawija lainnya. Ketika hari pelaksanaan akan tiba, para tetua adat (Mosalaki) akan mengumumkan hari (Nelu) kepada masyarakat desa setempat. Tradisi Paru Udu merupakan salah satu serangkaian acara dalam ritual Joka Ju. Dimana ritual Joka Ju dilaksanakan pada siang hari, kemudian dilanjutkan dengan acara atau tradisi Paru Udu pada malam harinya[2].

Ritual Joka Ju adalah ritual yangdilakukan untuk menolak bala dan hama pengganggu tanaman. Sedangkan tradisi Paru Udu itu sendiri adalah tradisi yang dilaksanakan untuk menghindar daribala atau penyakit. Karena, masyarakat Desa Mbuliwaralau berkeyakinan bahwa setelah selesai melakukan ritual Joka Ju, pada malam harinya akan terjadiperistiwa Ju Angi, yang dimana Ju Angi ini adalah roh jahat yang datang bersama angin keperkampungan untuk mencari korban pada masyarakat desa. Maka dari itulah tradisi Paru Udu dilaksanakan.

Prosesi tradisi Paru Udu di Desa Mbuliwaralu dimulai dari ritual Joka Ju. Yang dimana untuk melakukan ritual Joka Ju, masyarakat setempat khususnya kaum laki-laki diperintahkan oleh ketua adat (Mosalaki) untuk mengambil ayam dan beras dari rumah ke rumah masyarakat di wilayah kekuasannya, yang nantinya akan digunakan sebagai bahan sesajian untuk dipersembahkan kepada para leluhur di tempat ritual Joka Ju dilaksanakan. Setelah selesai melakukan ritual, dilanjutkan dengan prosesi selanjutnya yaitu Paru Udu.

Prosesi tradisi Paru Udu itu sendiri dimulai dari melakukan persiapan-persiapan yaitu ketupat (Are Gau), daging ayam (Nake Manu), alas tidur (te'e), pelita (Ila Lo'o) sebagai simbol roh jahat (Ju Angi) dan sekaligus sebagai bekal untuk dimanfaatkan ditempat atau lokasi tradisi Paru Udu dilksanakan. Setelah tiba dilokasi, semua masyarakat dikumpulkan pada satu tempat. Kemudian ketua adat (Mosalaki) melakukan ritual, yang dilanjutkan dengan teriakan bahasa adat berupa pantangan yang harus diikuti oleh masyarakat, yang bertujuan agar terhindar dari mara bahaya atau bala yang akan menimpa kehidupan masyarakat Desa Mbuliwaralau pada umumnya. Puncak dari prosesi tradisi Paru Udu adalah masyarakat secara bersamasama menyantap makanan yang telah disediakan sebelumya. Masyarakat Mbuliwaralau berkeyakinan bahwa setelah menyantap makanan tersebut, tidak akan terjadi bala, penyakit ataupun kematian.

Masyarakat Desa Mbuliwaralau masih memilih untuk tetap mempertahankan tradisi Paru Udu sebagai salah satu bentuk budaya, karena tradisi Paru Udu sudah dijadikan oleh masyarakat setempat sebagai salah satu ajang untuk mempererat tali silaturahmi, agar dalam kehidupan bermasyarakat tetap terjalin dengan baik dan harmonis. Selain itu, di dalam tradisi Paru Udu 
juga mengandung nila-nilai yang diyakini oleh masyarakat Mbuliwaralau sebagai roh dan makna dari kehidupan masyarakat. Dalam suatu tradisi pada umumnya terdapat nilai-nilai dasar yang terkandung di dalamnya yaitu: 1) nilai sosial, adalah kasih sayang antara manusia dalam konteks hubungan interpersonal, yaitu ketika seorang dan yang lainnya saling memahami, menghargai antar sesama. 2) nilai agama, yaitu nilai yang memiliki kadar besar yang paling kuat. Nilai ini bersumber pada kebenaran yang tertinggi yang datang dari tuhan. 3) nilai moral, yang dimaksud adalah kesadaran akan betapa pentingnya nilai-nilai sosial etika dan budaya, dimana budaya itu hidup dan berkembang. Nilai-nilai tersebut akan nampak pada simbol-simbol, slogan atau yang lainnya yang kelihatan kasat mata. Sikap, tindak laku, gerak-gerik dan kepercayaan yang tertanam yang mengatur dan menjadi kerangka acuan dalam bertindak dan berperilaku[3].

Nilai-nilai yang akan dikaji dalam penelitian ini, yang berkaitan dengan tradisi Paru Udu dalam ritual Joka Ju diantaranya adalah nilai sosial, nilai agama, nilai moral, nilai budaya dan nilai ekonomi. Nilai sosial adalah nilai yang mengacu kepada apa yang baik dan benar oleh orang secara umum. 2) Nilai agama atau raligi adalah nilai yang mengacu kepada apa yang dipilih oleh seseorang dari orientasi religius, keyakinan kepada Tuhan Yang Maha Esa atau sesuatu yang bersifat non material. 3) Nilai moral yaitu nilai yang mengacu kepada pemilikan sesuatu sebagai hal yang baik atau menguntungkan, berdasarkan hubungan-hubungan sosial antar pribadi[6]. Pendapat lain mengatakan bahwa nilai budaya adalah konsep-konsep yang hidup dalam alam pikiran manusia mengenai hal-hal yang mereka anggap mulia, seperti dalam menentukan alternatif, cara-cara dan tujuan[4]. Sedangkan nilai ekonomi merupakan perilaku manusia dalam usahanya untuk memenuhi kebutuhan hidupnya.

Sesuai dengan pendapat-pendapat tersebut di atas, nilai-nilai yang terdapat dalam tradisi Paru Udu dalam ritual Joka Ju adalah:1). Nilai sosial yang terdapat dalam tradisi Paru Udu dalam ritual Joka Ju, tergambar jelas ketika masyarakat melakukan gotong royong, partisipasi, saling membantu dalam persiapan dan menyelesaikan proses ritual Joka Ju sampai dengan acara atau tradisi Paru Udu yang dilakukan pada malam harinya. 2). Nilai agama yang terdapat dalam teradisi Paru Udu dalam ritual Joka Ju dapat dilihat bahwa, tradisi ini dilakukan untuk menolak bala dan hama pengganggu tanaman dan, sebagai bentuk syukur kepada wujud tertinggi (Tuhan yang Maha Esa) atas limpahan hasil panene yang didapatkan masyarakat sebelumnya, serta meminta kepada Tuhan untuk terhindar dari roh jahat (Ju Angi). 3) Nilai moral dalam tradisi Paru Udu dalam ritual Joka Ju dapat dilihat dari kebiasaan sgotong-royong masyarakat Desa Mbuliwaralau, rasa partisipasi saling membantu, mulai dari persiapan sampai pada pelaksanaan ritual Joka $\mathrm{Ju}$ dan Paru Udu, mementingkan kepentingan bersama diatas kepentingan pribadi demi kelangsungan dan kelancaran pelaksanaan tradisi Paru Udu dalam ritual Joka Ju. 4) Nilai budaya dalam tradisi Paru Udu dalam ritual Joka Ju terlihat jelas bahwa tradisi Paru Udu merupakan hasil dari pada buah pikir masyarakat desa Mbuliwaralau yang menjadikannya sebagai suatu kebiasaan, kemudian diwariskan dari generasi ke generasi dan masih dijalankan hingga saat ini. 5) Nilai ekonomi yang dapat dilihat dari tradisi Paru Udu dalam ritual Joka Ju yaitu masyarakat Desa Mbuliwaralau memanfaatkan sebagian dari hasil panen yang didapatkan, kemudian diperjual belikan untuk memenuhi kebutuhan hidup sehari-hari.

Tradisi Paru Udu dalam ritual Joka Ju merupakan tradisi yang unik. Dikatakan sebagai tradisi yang unik, karena tradisi Paru Udu ini hanya terdapat di Desa Mbuliwaralau saja dan tidak terjadi di daerah manapun khususnya pada suku Lio di Kabupaten Ende. Keberadaan tradisi Paru Udu itu sendiri bukan sematamata hasil warisan saja, melainkan juga merupakan hasil dari keteguhan hati masyarakat Desa Mbuliwaralau untuk mempertahankan nilai-nilai budaya leluhur tersebut. Dengan demikian tujuan dalam artikel ini menjelaskan nilai-nilai yang terkandung pada tradisi Paru Udu dalam ritual Joka Ju masyarakat Mbuliwaralau Kabupaten Ende Nusa Tenggara Timur Indonesia.

\section{B. METODE PENELITIAN}

\section{Rancangan Penelitian}

Penelitian kualitatif yaitu suatu prosedur penelitian yang menghasilkan data deskriptif berupa kata-kata tertulis atau tulisan dari orang-orang dan perilaku yang dapat diamati, yang bermaksud untuk memahami fenomena tentang apa yang dialami oleh subjek penelitian misalnya perilaku, persepsi, tindakan, motivasi, dan lain-lain[5].

Penelitian deskriptif adalah yang bertujuan untuk menjelaskan atau mendeskripsikan suatu keadaan, peristiwa, objek apakah orang, segala sesuatu yang terkait dengan variabel-variabel yang bisa dijelaskan baik angka-angka maupun kata-kata[6]. Dalam hal ini, pendapat lain juga menyatakan bahwa penelitian deskriptif adalah suatu penelitian yang berupaya untuk mendeskripsikan, mencatat, menganalisis dan menginterprestasikan kondisi-kondisi yang sekarang ini terjadi atau ada.

Penelitian deskriptif kualitatif adalah suatu penelitian yang digunakan untuk memecahkan atau menjawab permasalahan yang sedang terjadi, dilakukan dengan menempuh langkah-langkah pengumpulan, klasifikasi, 
analisis/pengolahan data, membuat kesimpulan dan laporan, dengan tujuan untuk membuat gambaran tentang suatu keadaan secara objek dalam suatu deskriptif situasi[7].

Dari uraian di atas maka dapat peneliti simpulkan bahwa penelitian deskriptif kualitatif yaitu suatu pendekatan untuk menjelaskan dan mendeskripsikan suatu keadaan, fenomena, peristiwa, dan objek saat melakukan penelitian. Untuk itu dalam penelitian ini, peneliti menggunakan jenis penelitian kualitatif dengan menggunakan pendekatan deskriptif yaitu didasarkan atas data yang disajikan berupa data tentang kalimat untuk menyelidiki objek yang tidak dapat di ukur dengan angka-angka yang berkaitan dengan nilai-nilai yang terkandung di dalam tradisi Paru Udu dalam ritual Joka Ju di Desa Mbuliwaralau kecamatan Wolowaru Kabupaten Ende.

\section{Subyek Penelitian}

Penelitian yang dilakukan ini tergolong penelitian kualitatif, maka subjek penelitian merupakan pihakpihak yang menjadi sasaran penelitian atau sumber yang dapat memberikan informasi. Jadi subyek penelitian ini adalah warga Desa Mbuliwaralau Kecamatan Wolowaru Kabupaten Ende.

Subjek penelitian akan menjadi informan yang akan memberikan berbagai macam informasi yang diperlukan selama proses penelitian. Informan adalah orang yang dimanfaatkan untuk memberikan informasi tentang situasi dan kondisi latar penelitian[4]. Jadi, dia harus mempunyai banyak pengalaman tentang latar penelitian, dan yang akan menjadi informan tersebut, dipilih secara purposive dengan tujuan tertentu. Purposive sampling adalah teknik pengambilan sampel sumber data dengan pertimbangan tertentu. Pertimbangan tertentu ini misalnya orang tersebut dianggap paling tau tentang apa yang kita harapkan, atau mungkin dia sebagai penguasa, sehingga akan memudahkan peneliti menjelajahi objek situasi sosial yang diteliti[10].

Berdasarkan keterangan di atas dapat disimpulkan bahwa, untuk mendapatkan subyek penelitian dalam penelitian ini adalah dengan menggunakan purposive sampling. Purposive sampling merupakan teknik pengumpulan data dengan cara pertimbangan tertentu yaitu orang-orang yang dianggap tau tentang tradisi Paru Udu. Seperti yang telah disebut diatas, maka yang menjadi subyek atau informen dari penelitian ini yaitu ketua adat (Mosalaki), tokoh adat dan tokoh masyarakat pada umumnya.

\section{Jenis dan Sumber Data}

a. Jenis Data

Dalam pelaksanaan penelitian, ada dua jenis data yakni data kualitatif dan data kuantitatif. Data kualitatif adalah data-data yang berupa kata atau kalimat, uraian, gambar dan foto. Sedangkan jenis data kuantitatif adalah data yang berbentuk angka, bilangan sesuai dengan bentuknya[8].
Adapun jenis data yang digunakan dalam penelitian ini adalah data kualitatif bukan kuantitatif, karena tidak berhubungan dengan angka-angka, namun dijelaskan dengan kata-kata atau kalimat. Dari jenis data yang digunakan dalam jenis data kualitatif, yaitu dengan cara menjelaskan secara sistematis, analitis, dan logis dari permasalahan.

b. Sumber Data

Dalam penelitian ini terdapat dua sumber data yaitu:

1) Sumber Data Primer

Sumber data primer adalah sumber data yang langsung memberikan data kepada pengumpul data, yang berasal dari responden dan informen[9].

2) Sumber Data Sekunder

Sumber data sekunder adalah sumber data yang tidak langsung memberikan data kepada pengumpul data, misalnya lewat orang lain atau lewat dokumen dan artikel mengenai masalah yang diteliti[9].

Berdasarkan teori di atas, maka yang menjadi data primer dalam penelitian ini adalah hasil pengumpulan data melalui observasidan wawancara. Sedangkan yang menjadi data sekunder adalah dokumen-dokumen mengenai acara Paru Udu dalam ritual Joka Ju.

\section{Teknik Pengumpulan Data}

a. Observasi

Observasi atau pengamatan adalah teknik pengumpulan data yang digunakan dengan cara mengamati dan mencatat secara sistematis, peristiwa dan gejala-gejala yang diselidiki[10].

Observasi diklasifikasikan menjadi observasi berpartisipasi (participant observation), observasi yang secara terang-terangan dan tersamar (overt observation dan covert observation), dan observasi yang tak berstruktur (unstructured observation)[9].

1) Observasi Partisipatif

Dalam observasi ini, peneliti terlibat dengan kegiatan sehari-hari orang yang sedang diamati atau yang digunakan sebagai sumber data penelitian. Dengan obervasi partisipan ini, maka data yang diperoleh akan lebih lengkap, tajam, dan sampai mengetahui pada tingkat makna dari setiap perilaku yang nampak.

2) Observasi Terus Terang atau Tersamar

Dalam hal ini, peneliti dalam melakukan pengumpulan data menyatakan terus terang kepada sumber data, bahwa ia sedang melakukan penelitian. Tetapi dalam suatu saat peneliti juga tidak terus terang atau tersamar dalam observasi, hal ini untuk menghindari kalau suatu data yang dicari merupakan data yang masih dirahasiakan.

3) Observasi Tak Berstruktur

Observasi tidak berstruktur adalah observasi yang tidak dipersiapkan secara sistematis tentang apa yang akan diobservasi. Hal ini dilakukan karena peneliti tidak tahu secara pasti tentang apa yang akan diamati.

Berdasarkan uraian di atas observasi yang digunakan dalam penelitian ini adalah observasi partisipatif. Dimana peneliti berinteraksi secara penuh dalam situasi 
sosial dengan subjek penelitian. Peneliti berperan serta dalam kegiatan-kegiatan subjek kegiatan atau orang yang digunakan sebagai sumberdata penelitian, dan observasi peran serta dalam penelitian ini dilakukan berulang-ulang sampai diperoleh data yang diperlukan.

\section{b. Wawancara}

Wawancara adalah merupakan pertemuan dua orang untuk bertukar informasi dan ide melalui tanya jawab, sehingga dapat dikonstruksikan makna dalam suatu topik tertentu[10]. Sedangkan pendapat lain juga menyatakan bahwa wawancara adalah percakapan dengan maksud tertentu. Percakapan itu dilakukan oleh dua pihak yaitu pewawancara (interviewer) yang mengajukan pertanyaan dan terwawancara (interviewee) yang memberikan jawaban atas pertanyaan itu.

Dari beberapa pendapat di atas, dapat penulis simpulkan bahwa wawancara dapat dikatakan sebagai percakapan atau dialog yang dilakukan oleh kedua belah pihak yaitu pewawancara dan yang diwawancara (responden) untuk memberikan jawaban atas pertanyaan dengan maksud tertentu.

Wawancara terbagi atas beberapa macam yaitu wawancara terstruktur, semiterstruktur, dan tidak tersruktur.

1) Wawancara Terstruktur (Structured Interview)

Wawancara terstruktur digunakan sebagai teknik pengumpulan data, bila peneliti atau pengumpul data telah mengetahui dengan pasti tentang infomasi apa yang akan diperoleh. Oleh karena itu dalam melakukan wawancara, pengumpul data telah menyiapkan instrumen penelitian berupa pertanyaan-pertanyaan tertulis yang alternatif jawabannya pun telah disiapkan.

2) Wawancara Semi Terstruktur (Semistructure Interview).

Jenis wawancara ini sudah termasuk dalam kategori in-dept interview, dimana pelaksanaannya lebih bebas bila dibandingkan dengan wawancara terstruktur.

3) Wawancara Tak Terstruktur (Unstructure Interview).

Wawancara tidak terstruktur, adalah wawancara yang bebas dimana peneliti tidak menggunakan pedoman wawancara yang telah tersusun secara sistematis dan lengkap untuk pengumpulan datanya.

Berdasarkan uraian di atas, maka teknik wawancara yang digunakan dalam penelitian ini adalah teknik wawancara semi terstruktur, dimana wawancara bersifat luwes dan menggunakan pedoman wawancara dengan bentuk pertanyaan hanya garis-garis besar permasalahan yang akan ditanyakan. Wawancara ini menggunakan kata-kata atau pertanyaan yang dapat diubah saat wawancara, dengan penyesuaian kebutuhan dan situasi wawancara, dengan catatan tidak menyimpang dari informasi yang dibutuhkan untuk penelitian saat wawancara berlangsung. Wawancara semi terstruktur digunakan untuk mewawancarai subyek utama yaitu ketua adat (Mosalaki), tokoh adat dan tokoh masyarakat.

\section{c. Dokumentasi}

Dokumentasi merupakan teknik pengumpulan data yang ketiga yang dilakukan oleh peneliti untuk melengkapi data yang dibutuhkan dalam penelitian, Dokumen merupakan catatan peristiwa yang sudah berlalu. Dokumen bisa berbentuk tulisan, gambar, atau karya-karya monumental dari seseorang. Dokumen yang berbentuk tulisan misalnya catatan harian, sejarah kehidupan (life histories), caritera, biografi, peraturan, kebijakan. Dokumen yang berbentuk karya misalnya karya seni yang dapat berupa gambar, patung, film dan lain-lain[11].

Berdasarkan teorinya Sugiyono di atas dapat disimpilkan bahwa dalam dokumentasi ini peneliti akan menggunakan foto, catatan tentang Paru Udu atau data data-data berupa tulisan tentang tradisi Paru Udu dan ritual Joka Ju. Teknik ini dilakukan karena dirasakan cukup perlu dalam memberikan sumbangsi sebagai data penguat, sebab wujudnya berbentuk fisik, misalnya seperti hasil rekaman (record), wawancara yang berbentuk audio maupun visual. Dokomen-dokumen tersebut juga dirasakan cukup penting dan memiliki poin yang cukup besar dalam memperkuat data.

\section{Teknik Analisis Data}

Analisis data adalah proses-proses mancari dan menyususn secara sistematis data yang diperoleh dari hasil wawancara, catatan lapangan, dan dokumentasi dengan cara mengorganisasikan data kedalam kategori, menjabarkan kedalam unit-unit, melakukan sintesa, menyusun kedalam pola-pola, memilih mana yang penting yang akan dipelajari dan membuat kesimpulan sehingga dipahami oleh diri sendiri maupun orang lain[8].

Analisis data dalam penelitian kualitatif dilakukan sejak sebelum memasuki lapangan, selama di lapangan dan setelah selesai di lapangan. Dalam hal ini pendapat lain menyatakan bahwa analisis telah mulai sejak merumuskan dan menjelaskan masalah, sebelum turun ke lapangan dan berlangsung terus sampai penulisan hasil penelitian. Analisis data menjadi pegangan bagi peneliti selanjutnya sampai jika mungkin, teori yang grounded. Analisis data dalam penelitian kualitatif, dilakukan pada saat pengumpulan data berlangsung dan setelah selesai pengumpulan data pada periode tertentu. Pada saat wawancara, peneliti sudah melakukan analisis terhadap jawaban yang diwawancarai. Bila jawaban yang diwawancarai setelah dianalisis terasa belum memuaskan, maka peneliti akan melanjutkan pertanyaan lagi sampai tahap tertentu, diperolah data yang kredibel.

Metode analisis data yang digunakan dalam penelitian ini yaitu metode analisis kualitatif bersifat deskriptif. Aanalisis data dengan menggunakan metode kualitatif 
bersifat deskriptif yaitu analisis data dengan menggunakan metode kualitatif bersifat deskriptif yaitu dengan memperhatikan data-data yang diperoleh dari penelitian kepustakaan, sehingga dapat diperoleh gambaran dan kesimpulan dari permasalahan yang dibahas, data yang diperoleh dilihat kelengkapannya, kejelasannya serta keseragaman data yang diperlukan, selanjutnya data tersebut disusun secara sistematis, dan konsisten agar memudahkan peneliti menganalisis data yang ada, kemudian diolah dan dianalisis secara kualitatif dengan mengetengahkan data yang tidak berupa angka-angka atau bilangan, melainkan dalam bentuk uraian kalimat berdasarkan hasil penelitian dilapangan[18].

Aktifitas dalam analisis data kualitatif dilakukan secara interaktif dan berlangsung secara terus-menerus sampai tuntas, hingga datanya jenuh. Aktifitas tersebut yaitu reduksi data (data reduction), penyajian data (data displai), penarikan kesimpulan (conclusion drawing/verification).

\section{a. Reduksi Data (Data Reduction)}

Jika data yang diperoleh dari lapangan jumlahnya cukup banyak, untuk itu maka perlu dicatat, secara teliti dan rinci. Semakin lama peneliti dilapangan maka jumlah data akan semakin banyak, kompleks dan rumit. Untuk itu perlu dilakukan analisis melalui reduksi data. Mereduksi data berarti merangkum, memilih hal-hal yang pokok, memfokuskan pada hal-hal yang penting dicari tema dan polanya serta membuang yang tidak perlu, dengan demikian data yang telah direduksi akan memberikan gambaran yang lebih jelas dan mempermudah peneliti untuk melakukan pengumpulan data selanjutnya dan mencari bila diperlukan.

b. Penyajian Data (Data Display)

Setelah data direduksi, maka langkah selanjutnya adalah mendisplaykan data. Melalui penyajian data tersebut maka data terorganisasikan, tersususn dalam pola hubungan sehingga akan mudah dipahami.

\section{c. Penarikan Kesimpilan (Conclution Drawing/verification)}

Setelah melakukan penyajian, maka langkah selanjutnya adalah penarikan kesimpulan atau verification ini didasarkan pada reduksi data yang merupakan jawaban atas masalah yang diangkat dalam penelitian. Kesimpulan awal masih bersifat sementara dan berubah apabila tidak ditemukan bukti-bukti yang kuat, yang mendukung pada tahap pengumpulan data berikutnya. Tetapi apabila kesimpulan yang dikemukakan tahap awal, didukung oleh bukti-bukti yang valid dan konsisten saat peneliti kembali ke lapangan mengumpulkan data, maka kesimpulan yang dikemukakan merupakan kesimpulan yang kredibel..

\section{HASIL DAN PEMBAHASAN}

Tradisi Paru Udu dalam ritual Joka Ju adalah warisan budaya leluhur yang diwariskan dari generasi ke generasi dengan maksud dan tujuan tertentu. Seperti halnya yang terlihat dari pelaksanaan tradisi Paru Udu dalam ritual Joka Ju di Desa Mbuliwaralau. Ritual atau upacara tradisi ini bertujuan antara lain untuk mengungkapkan rasa syukur kepada Tuhan Yang Maha Esa atas yang telah memberikan keselamatan, kesejahteraan, dan ketentaraman dalam masyarakat, serta menjadi do'a supaya kedepannya kehidupan masyarakat Desa Mbuliwaralau tetap tentram dan senantiasa dilimpahi rezeki dari hasil tanaman yang telah ditanam dan dijauhi oleh bahaya hama yang mengganggu tanaman mereka.

Setiap aktifitas budaya pasti memiliki nilai yang tersirat di dalam pelaksanaannya. Entah disadari atau tidak, nilai dari suatu tradisi akan terus ada selama kebudayaan itu dipelihara. Nilai adalah keyakinan preferensi ataupun asumsi mengenai apa yang diinginkan atau dianggap baik oleh manusia. Nilai pada hakikatnya mengarahkan perilaku dan pertimbangan seseorang, tetapi ia tidak menghakimi apakah sebuah perilaku tertentu itu salah atau benar[12].

Tidak dapat dipisahkan bahwa, dalam kehidupan bermasyarakat manusia membutuhkan orang lain untuk berinteraksi. Masyarakat sebagai komunitas yang terdiri dari individu-individu dengan berbagai macam aktivitas sosialnya sehingga terbentuknya nilai sosial dalam kehidupan masyarakat tersebut.

Nilai sosial terbentuk karena masih adanya fungsi tradisi bagi masyarakat. Salah satunya adalah tradisi Paru Udu dalam ritual Joka Ju yang terdapat di Desa Mbuliwaralau Kecamatan Wolowaru Kabupaten Ende, yang dimana didalam pelaksanaan tradisi ini terdapat beberapa nilai yang terkandung didalamnya diantaranya adalah:

1. Nilai Sosial

Nilai sosial merupakan sesuatu yang dianggap berharga oleh masyarakat, yaitu anggapan masyarakat tentang sesuatu yang diharapkan, indah, dan benar serta memiliki manfaat jika dilakukan. Nilai sosial merupakan sikap dan perasaan masyarakat untuk menentukan apa yang dianggap benar dan salah. Tradisi Paru Udu dalam ritual Joka Ju merupakan sebuah tradisi yang dianggap baik oleh masyarakat Desa Mbuliwaralau karena, di dalam pelaksanaannya masyarakat dapat berinteraksi satu dengan yang lainnya, saling mendukung untuk keselamatan dan kemajuan bersama. Hal tersebut diperkuat oleh pendapat yang dikemukakan tokoh masyarakat Desa Mbuliwaralau yang menyatakan bahwa tradisi ini sudah dijalankan secara turun-temurun oleh ketua adat (Mosalaki) bersama masyarakat. Jika tradis Paru Udu dalam ritual Joka Ju tidak dilaksanakan maka Mosalaki bersama masyarakatnya akan mendapatkan bala atau marabahaya seperti kekeringan dan tidak bisa mendapatkan hasil panen yang baik. Jika tradisi ini dilaksanakan maka itu dipandang sebagai suatu langkah yang benar karena menjalakan tradisi ini merupakan sebuah amanat yang diberikan oleh nenek moyang kami dan kami harus menjalankanya agar kami atau semua 
masyarakat terhidar dari bala atau musibah yang terjadi secara tidak wajar”. (Bapak Reso, wawancara 16, April 2019).

Nilai sosial terdiri dari nilai material, nilai vital dan nilai rohani. Nilai-nilai tersebut dalam pelaksanaan tradisi Paru Udu dalam ritual Joka Ju dapat dijelaskan seperti berikut:

\section{a. Nilai Material}

Nilai material dalam tradisi Paru Udu dalam ritual Joka Ju dapat didlihat dari sajian atau hidangan sesembahan yang dipersiapkan untuk para leluhur dalam prosesi Po'o Are guna untuk melakukan pelaksanaan ritual (Kuwi Roe). Untuk mempersiapkan sesajian tersebut masyarakat memanfaatkan batang bambu sebagai wadah untuk memasak nasi. Hal ini didukung oleh pendapat yang dikemukakan tokoh adat Desa Mbuliwaralau bahwa untuk menyediakan sesajian atau sesembahan untuk para leluhur, kami membutuhkan parang untuk memotong bambu dan kayu bakar, dan yang paling penting adalah ayam, telur ayam dan beras (Bapak Jido wawancara 17, April 2019).

Selain dipersembahkan kepada para leluhur, hidangan tersebut juga dinikmati oleh semua masyarakat yang ikut dalam pelaksanaan ritual tersebut.

b. Nilai Vital

Nilai vital yang terkandung dalam tradisi Paru Udu dalam ritual Joka Ju terlihat jelas dari tujuan dan fungsi pelaksanaan tradisi tersebut yaitu sebagai wujud syukur kepada Tuhan Yang Maha Esa sekaligus sebagi tolak bala dari roh jahat yang datang bersama angin ( $J u$ Angi) dan segala marabahaya lainnya sehingga masyarakat Desa Mbuliwaralau dapat menjalani hidup dengan tenang. Hal tersebut diperkuat oleh pendapat yang di kemukakan oleh selaku tokoh adat Desa Mbuliwaralau yang menyatakan bahwa pelaksanaan tradisi Paru Udu dalam ritual Joka Ju ini agar semua masyarakat terhidar dari roh jahat (Ju Angi) dengan memberikan sesembahan kepada para leluhur dan memohon kepada Tuhan agar semua masyarakat selalu diberikan rizki atau hasil panen yang baik (Bapak Mbira, wawancara 18, April 2019).

c. Nilai Rohani

Nilai rohani dalam tradisi Paru Udu dalam ritual Joka Ju yaitu nilai keagamaan dan nilai moral.

1) Nilai Keagamaan (nilai religius)

Dalam tradisi Paru Udu dalam ritual Joka $J u$ nilai keagamaan atau religius terlihat jelas dari sikap sembah, rasa hormat dan syukur masyrakat Desa Mbuliwaralau kepada Tuhan Yang Maha Esa atas hasil panen yang melimpah. Ekspresi rasa syukur tersebut ditunjukan melalui pelaksanaan ritual adat tradisi Paru $U d u$ dalam ritual Joka Ju tersebut. Hal ini diperkuat oleh pendapat ketua adat (Mosalaki) yang mangatakan bahwa tradisi Paru Udu dalam ritual Joka Ju dilaksanakan selain sebagai untuk menghindari roh jahat (Ju Angi), tradisi ini juga dilaksanakan sebagai bentuk syukur kepada wujud tertinggi atas hasil panen yang melimpah telah didapatkan sebelumnya dan sekaligun meminta perlindungan agar tanaman yang akan ditanam nantinya terhindar dari hama yang akan merusak tanaman tersebut (Bapak Ismail, wawancara 15, April 2019).

2) Nilai Moral

Nilai moral dari tradisi Paru Udu dalam ritual Joka Ju antra lain yaitu nilai gotongroyong, ketika masyarakat bersama-sama saling membantu mulai dari mempersiapkan sampai pada pelaksanaan ritual selesai, nilai kebersamaan yaitu terlihat jelas dalam pelaksanaan tradisi Paru Udu dalam ritual Joka Ju dengan melibatkan orang banyak dan mempunyai peran dan fungsi yang berbeda dalam setiap proses yang dilaksanakan, nilai musyawarah terlihat jelas ketika masyarakat bertukar pendapat untuk menentukan tempat pelaksanan tradisi Paru Udu dalam ritual Joka Ju dilaksanakan. Rasa ikhlas partisipasi saling membantu, serta kerukunan antar warga yang mementingkan kepentingan bersama diatas kepentingan pribadi demi kelangsungan dan kelancaran pelaksanaan tradisi Paru Udu dalam ritual Joka Ju sehingga dapat mencapai tujuan bersama. Hal ini sesuai dengan pernyataan yang disampaikan oleh tokoh masyarakat bahwa untuk menyipkan bahan-bahan dalam pelaksanaan ritual kami melakukan kerja sama antara masyarakat dengan ketua adat (Mosalaiki). Kami bergotong-royong menyipkan semua bahan dan peralatan yang dibutuhkan mulai dari prosesi Pana Manu, Po'o Are, sampai dengan Kuwi Roe dan pada malam Paru Udu juga kami secara bersama-sama melakukan musyawarah menentukan lokasi yang baik untuk melaksanakan Paru Udu (Bapak Reso, wawancara 16, April 2019).

2. Nilai Budaya

Nilai budaya dalam tradisi Paru Udu dalam ritual Joka Ju sudah tergambar jelas dari awal, yang dimana tradisi merupakan sebuah budaya, budaya merupakan hasil karya manusia yang tanpa disadari akan menjadi adat istiadat. Tradisi Paru Udu dalam ritual Joka Ju ini juga merupakan hasil karya atau buah pikiran masyarakat Desa Mbuliwaralau yang memilikiki tatacara 
pelaksanaan tersendiri dan telah menjadi kebiasaan masyarakat Desa Mbuliwaralau pada umumnya. Sebagaiman yang dikatakana oleh tokoh masyarakat Desa Mbuliwaralau bahwa tradisi Paru Udu dalam ritual Joka Ju ini sudah menjadi kebiasaan masyarakat dari dulu sampai sekarang, yang ditandai dengan masyarakat desa setempat yang masih melakukan setiap prosesi atau tahapan pelaksanaan tradisi Paru Udu dalam ritual Joka $J u$ yang dilaksanakan satu kali disetiap tahunnya (Bapak Reso, wawancara 15, April 2019).

Kebiasaan tersebut diwariskan oleh leluhurleluhur atau nenek moyang kepada generasi dibawahnya, dan sampai sekarang masih terus hidup, dilestarikan dan dijaga eksitensinya.

\section{Nilai Ekonomi}

Nilai ekonomi dalam tradisi Paru Udu dalam ritual Joka Ju dapat dilihat dari usaha masyarakat Desa Mbuliwaralau yang telah mendapatkan hasil panen yang baik sebelumnya, dan kemudian dari hasil panen tersebut diperjualbelikan oleh masyarakat Desa Mbuliwaralau untuk memenuhi kebutuhan hidup yang lainnya. Sebagaimana yang disampaikan oleh ketua adat (Mosalaki) bahwa, dengan melaksanakan tradisi Paru Udu dalam ritual Joka Ju ini justru akan mendapatkan hasil panen yang melimpah dan sangat membantu kami dalam memenuhi kebutuhan sehari-hari (Bapak Ismail, wawancara 15, April 2019).

Tidak hanya itu, masyarakat Desa Mbuliwaralau juga mendapatkan kesempatan dalam berdagang pada saat prosesi tradisi Paru Udu berlangsung, sehingga dapat meningkatkan nilai jual dan pendapatan ekonomi yang lebih baik. Jadi dapat dikatakan bahwa dengan adanya tradisi Paru Udu dalam ritual Joka Ju ini, dapat meningkatkan nilai ekonomi masyarakat Desa Mbuliwaralau.

Masyarakat Desa Mbuliwaralau yang menjunjung tinggi nilai-nilai luhur, mempunyai anggapan bahwa manusia tidak dapat hidup sendirian tetapi, selalu tergantung kepada sesamanya. Oleh karena itu, tradisi Paru Udu dalam ritual Joka Ju yang menyangkut kegiatan seluruh masyarakat ditujukan untuk kepentingan bersama.

Hal ini disebabkan pada dasarnya, tradisi tersebut untuk kepentingan bersama, memberikan kesejahteraan, ketenteraman dan keselamatan masyarakat desa Mbuliwaralau.

\section{TEMUAN DAN DISKUSI}

Adapun tahapan-tahapan dalam proses pelaksanaan tradisi Paru Udu dalam Ritual Joka Ju sebagai berikut:

1. Pai Nelu (pengumuman hari pelaksanaan)

2. Pana Manu (mengambil ayam, beras dan bahan-bahan atau perlengkapan lainnya yang dibutuhkan yang nantinya akan di pergunakan sebagai bahan sesembahan kepada roh-roh leluhur)
3. Po'o Are (memasak nasi menggunakan bambu dengan cara dibakar, sekaligus membatu ketua adat menyipkan bahan sesembahan yang akan dipersembahkan kepada roh-roh leluhur)

4. Kuwi Roe (pelaksanaan ritual) yaitu proses pemberian sesembahan kepada roh-roh leluhur yang di lakukan oleh ketua adat (Mosalaki)

5. Paru Udu (lari ke ujung sebelah timur perbatasan perkampungan) kegatan ini di lakukan oleh ketua adat Mosalaki dan diikuti oleh seluruh masyarakat Desa Mbuliwaralau.

Tradisi Paru Udu merupakan sebuah adat istiadat yang terus menerus yang dilakukan masyarakat Ende setiap tahun melalui tahapan pengumuman hari pelaksanaan, mengambil ayam, beras dan bahan-bahan atau perlengkapan lainnya yang dibutuhkan yang nantinya akan di pergunakan sebagai bahan sesembahan kepada roh-roh leluhur, memasak nasi menggunakan bambu dengan cara dibakar, sekaligus membatu ketua adat menyipkan bahan sesembahan yang akan dipersembahkan kepada roh-roh leluhur, proses pemberian sesembahan kepada roh-roh leluhur yang di lakukan oleh ketua adat (Mosalaki), dan lari ke ujung sebelah timur perbatasan perkampungan. Tradisi tersebut menurut masyarakat flores sebagai ungkapan rasa syukur kepada tuhan yang maha esa atas karunia yang berikan kepada manusia telah diberikan panen padi, tanah yang subur, palawija dan umbi-umbian.

Hal tersebut sejalan dengan penelitian yang menjelaskan bahwa pada dasarnya kearifan lokal masyarakat disarikan dari pengalaman masyarakat lama yang sangat akrab dengan lingkungannya dan sudah lama hidup dalam budaya masyarakat peladang. Kearifan lokal adat, suatu kondisi sosial dan budaya yang didalamnya terkandung khasanah nilai-nilai budaya yang menghargai dan adaptif dengan alam sekitar, dan tertata secara ajeg dalam suatu tatanan adat istiadat suatu masyarakat. Walau sering dianggap kuno, nilai-nilai yang mereka ajarkan dan praktek yang mereka jalankan masih merupakan cara yang terbaik untuk memelihara lingkungan di zaman post-modern[13].

Selain itu tradisi atau kearifan local daerah memiliki fungsi berupa 1) Masyarakat adat memiliki kearifan lokal terkait dengan kepemimpinan, interaksi sosial, dan tata cara hidup; 2) nilai-nilai kearifan lokal di dalamnya meliputi kepedulian lingkugan, kerjasama, konsisten, kreativitas, kemandirian, kebersamaan, kesederhanaan, dan tanggungjawab; 3) nilai-nilai kearifan lokal tersebut dapat diintegrasikan dalam materi mata pelajaran di kelas VII dan VIII, sehingga masyarakat adat dapat menjadi alternatif sumber belajar IPS[14].

Adapun proses pelaksanan tradisi Paru Udu itu sendiri antara lain:

\section{a. Proses persiapan}

Proses ini dilakukan oleh seluruh masyarakat untuk menyiapkan perlengkapan mulai dari menyiapkan: 
1) Ila Lo'o (pelita) sebagai alat penerang yang akan di gunanakan di lokasi atau tempat dimana tradisi Paru Udu dilaksanakan

2) Are Gau dan Nake Manu (ketupat dan daging ayam yang sudah dimasak) sebagi bekal makanan sekaligus simbol roh jahat yang dating bersama angin (Ju Angi)

3) Te'e Lani (tikar atau perlengkapan tidur) yang nantinya akan digunakan sebagai alas tidur.

b. Proses pelaksanaan ritual

Proses pelaksanaan ritual dalam tradisi Paru Udu yang dalam bahasa adat suku Lio Desa Mbuliwaralau disebut dengan Pai Kera (teriak). Prosesi ritual ini dilakukan oleh ketua adat (Mosalaki) dan diikuti oleh seluruh masyarakat desa setempat, dan berlangsung dalam keadaan gelap.

c. Proses puncak

Proses atau tahap puncak pelaksanaan dari tradisi Paru Udu adalah Ka Are Gau dan Pesa Nake Manu yaitu menyantap ketupat dan daging ayam yang telah disediakan sebelumnya secara bersama-sama. Yang mana ketupat dan daging ayam merupakan simbol roh jahat yang datang bersama angin atau yang dalam bahsa adat suku Lio Desa Mbuliwaralau disebut dengan Ju Angi.

Adapun nilai-nilai yang terkandung di dalam tradisi

Paru Udu dalam Ritual Joka Ju yaitu:

a. Nilai social

Nilai sosial meliputi nilai material, nilai vital, dan nilai rohani. Dalam nilai rohani terdapat nilai religius dan nilai moral. Nilai moral yaitu meliputi nilai kerukunan, nilai musyawarah, nilai kebersamaan dan nilai gotong-royong.

Nilai sosial dalam tradisi suatu daerah dapat memberikan penguatan pada nilai norma, sikap dan nilai kepercayaan bagi masyarakat adat dalam melaksanakan tradisi tersebut[15]. pembangunan.

b. Nilai budaya

Nilai budaya dalam tradisi Paru Udu dalam ritual Joka Ju sudah tergambar jelas dari awal, yang dimana tradisi merupakan sebuah budaya, budaya merupakan hasil karya manusia yang tanpa disadari akan menjadi adat istiadat.

Budaya tradisi local yang mengandung nilainilai luhur dapat dijadikan sebagai sarana pembangunan karakter bangsa sebagai bentuk pelestarian budaya yang lahir di daerah[16].

c. Nilai ekonomi.

Nilai ekonomi dalam tradisi Paru Udu dalam ritual Joka Ju dapat dilihat dari usaha masyarakat Desa Mbuliwaralau yang telah mendapatkan hasil panen yang baik sebelumnya, dan kemudian dari hasil panen tersebut diperjualbelikan oleh masyarakat Desa Mbuliwaralau untuk memenuhi kebutuhan hidup yang lainnya.

Desa Mbuliwara memiliki nilai budaya yang tinggi yakni tradisi paru udu yang dilaksanakan setiap tahunnya, dengan demikian tradisi Paru Udu ini dapat dikembangkan sebagai desa ekowisata. Dalam pengembangan desa ekowisata semaksimal mungkin harus dapat melibatkan masyarakat dan pemerintah daerah secara optimal dalam setiap proses-proses didalamnya[17]. Hal ini dilakukkan guna memberikkan ruang yang luas bagi masyarakat setempat untuk menikmati keuntungan secara ekonomi dari pengembangan ekowisata di wilayah desa tersebut.

\section{E. SIMPULAN DAN SARAN}

Hasil penelitian menunjukan bahwa tradisi tersebut mengandung nilai sosial, nilai budaya, dan nilai ekonomi. Nilai social meliputi nilai material nilai vital dan nilai rohani. Nilai rohani meliputi nilai religius dan nilai moral yang didalamnya terdapat nilai kerukunan, nilai musyawarah, nilai kebersamaan dan nilai gotong-royong.

Dengan demikian disarankan kepada masyarakat di Desa Mbuliwaralau Kecamatan Wolowaru Kabupaten Ende agar tetap melestarikan tradisi Paru Udu dalam ritual Joka Ju ini agar tradisi yang ada sejak dahulu ini dapat lihat dan dilakukan lagi oleh generasi penerusnya kelak, serta menjaga nilai-nilai yang terkandung di dalamnya.

\section{UCAPAN TERIMA KASIH}

Penulis mengucapkan terima kasih kepada pemerintah Desa Mbuliwaralau Kabupaten Ende Nusa Tenggara Timur, Universitas Muhammadiyah Mataram, dan para pihak-pihak yang senantiasa memberikan dukunga materi dan moral dan masukan kepada penulis sehingga artikel ilimiah ini selesai dengan baik.

\section{DAFTAR RUJUKAN}

[1] E. M. Setiadi, Ilmu sosial \& budaya dasar. Kencana, 2017.

[2] P. Supriyadin, U, "Padangan Masyarakat Trehadap Ritual Joka Ju Pada Masyarakat Desa Mbuliwaralau Kecamatan Wolowaru Kabupaten Ende.” Universitas Flores, Ende, 2016.

[3] N. Nurhayati and H. M. Yunan, "Tradisi Teka Ra Ne'e Dalam Prosesi Perkawinan Adat Pada Masyarakat Desa Boro di Kecamatan Sanggar Kabupaten Bima," Civ. Pendidikan-PenelitianPengabdian Pendidik. Pancasila dan Kewarganegaraan, vol. 6, no. 1, pp. 42-46, 2018.

[4] T. Mumfangati, "Warangan: Sebuah Dusun Sarat Seni Dan Tradisi," PENGANTAR REDAKSI, p. 266, 2007.

[5] L. J. Moleong, Metode Penelitian Kualitatif. 
Bandung: Remaja Rosdakarya, 2007.

[6] D. Mardalis, Metode penelitian: suatu pendekatan proposal. Bumi Aksara, 1995.

[7] H. Mahmud, "Metode Penelitian Pendidikan," Bandung CV Pustaka Setia, 2011.

[8] Sugiyono, "Metode penelitian kombinasi (mixed methods)," Bandung Alf., 2015.

[9] Sugiyono, Metode Penelitian Pendidikan $R \& D$. Bandung: Alfabeta, 2017.

[10] Sugiyono, "Dr. 2010," Metod. Penelit. Kuantitatif, Kualitatif, dan R\&D. Bandung CV Alf.

[11] Sugiyono, Metode Penelitian Pendidikan:(Pendekatan Kuantitatif, Kualitatif dan $R \& D$ ). Alfabeta, 2014.

[12] J. Japarudin, "Nilai-nilai Etis Agama dan Budaya dalam Praktik Pekerja Sosial," J. Ilm. Syi'ar, vol. 15, no. 2, pp. 59-70, 2015.

[13] I. Indrawardana, "Kearifan lokal adat masyarakat Sunda dalam hubungan dengan lingkungan alam," Komunitas Int. J. Indones. Soc. Cult., vol. 4, no. 1, 2012.

[14] L. Qodariah and L. Armiyati, "Nilai-Nilai Kearifan Lokal Masyarakat Adat Kampung Naga sebagai Alternatif Sumber Belajar," SOCIA J. Ilmu-Ilmu Sos., vol. 10, no. 1, 2013.

[15] A. Mustanir and M. R. R. Razak, "Nilai Sosial Budaya Pada Partisipasi Masyarakat Etnik Towani Tolotang Dalam Musyawarah Rencana Pembangunan," Pros. Konf. Nas. Ke-6 Asos. Progr. Pascasarj. Perguru. Tinggi Muhammadiyah Aisyiyah, pp. 1-7, 2017.

[16] A. D. Karmadi, "Budaya lokal sebagai warisan budaya dan upaya pelestariannya," Makal. disampaikan pada Dialog Budaya Drh. Jawa Teng. yang di sel enggarakan oleh Balai Pelestarian Sej. dan Nilai Tradis. Yogyakarta bekerjasama dengan Dinas Pendidik. dan Kebud. Propinsi Jawa Tengah, di Semarang, pp. 8-9, 2007.

[17] D. Satria, "Strategi pengembangan ekowisata berbasis ekonomi lokal dalam rangka program pengentasan kemiskinan di wilayah Kabupaten Malang," J. Indones. Appl. Econ., vol. 3, no. 1, 2009. 